\title{
Microbial communities of soda lakes and pans in the Carpathian Basin: a review
}

\author{
Tamás Felföldi ${ }^{1}$ (i)
}

Received: 20 February 2020 / Accepted: 20 July 2020 / Published online: 31 July 2020

(c) The Author(s) 2020

\begin{abstract}
In this review, I would like to summarize the current knowledge on the microbiology of soda lakes and pans of the Carpathian Basin. First, the characteristic physical and chemical features of these sites are described. Most of the microbiological information presented deals with prokaryotes and algae, but protists and viruses are also mentioned. Planktonic bacterial communities are dominated by members of the phyla Actinobacteria, Bacteroidetes and Proteobacteria; small-sized trebouxiophycean green algae and Synechococcus/Cyanobium picocyanobacteria are the most important components of phytoplankton. Based on the current knowledge, it seems that mainly temperature, salinity, turbidity and grazing pressure regulate community composition and the abundance of individual microbial groups, but the external nutrient load from birds also has a significant impact on the ecological processes.
\end{abstract}

Keywords Bacterioplankton $\cdot$ Algae $\cdot$ Extreme environment $\cdot$ Alkaline habitat $\cdot$ Food web

\section{Introduction}

Soda lakes are athalassic saline aquatic habitats with a dominance of sodium and (hydrogen) carbonate ions, and they have usually lower salinity than other types of saline lakes but stable alkaline pH (Hammer 1986; Boros and Kolpakova 2018). Probably the most well-known representatives of these environments are lakes in the East African Rift Valley (e.g. Lake Natron, Lake Magadi and Lake Bogoria) and the Mono Lake in the USA (Grant 2004; Schagerl 2016; Sorokin et al. 2014). On the other hand, many soda lakes and pans can be found in the Eurasian Steppe; the most western occurrence of these habitats is within the Carpathian Basin (Boros et al. 2013; Boros and Kolpakova 2018) (Fig. 1). Furthermore, according to our current knowledge, the only occurrence of these habitats within Europe is the Carpathian Basin.

Although the alkaline character of the water seems to be a good indicator for 'soda type' inland waters, recently, Boros and Kolpakova (2018) proposed a more straightforward

Tamás Felföldi

tamas.felfoldi@ttk.elte.hu

1 Department of Microbiology, Institute of Biology, ELTE Eötvös Loránd University, Pázmány Péter stny. 1/c., Budapest 1117, Hungary definition for soda lakes: ' $\mathrm{Na}^{+}$and $\mathrm{HCO}_{3}{ }^{-}+\mathrm{CO}_{3}{ }^{2-}$ are the first in the rank of dominant ions ( $>25 \mathrm{e} \%$ )'. They also draw attention to the fact that several studies published dealing with the microbiology of soda lakes (also from the Eurasian Steppe) were carried out on sites that do not belong to the 'soda type' according to this definition. The daily fluctuation of $\mathrm{pH}$ (e.g. due to photosynthetic activity) only adds ad hoc alkalinity to these saline lakes, while in the case of true soda lakes, the $\mathrm{pH}$ is buffered with carbonates and remains constantly high irrespectively of diurnal and seasonal changes in the water (Kirschner et al. 2002; Vörös and Boros 2010; Wetzel 2001). Additional information about water chemistry and about the genesis of soda lakes and pans is given elsewhere (Boros et al. 2014, 2017; Boros and Kolpakova 2018; Schagerl 2016).

Currently, there are approximately $80-100$ soda lakes and pans (including reconstructed and semi-natural lakes and pans) in the Carpathian Basin (Boros et al. 2013). These sites are ex lege protected areas in Hungary, and many of them are part of the UNESCO world heritage in Austria; some of them are also protected in Serbia. They have high protection priority in the Natura 2000 network of the European Union, several of them are Ramsar sites, since they are important continental stopover wetland sites of migrating birds, and many of them are situated within national parks (Boros et al. 2013, 2014, 2017; Gavrilović et al. 2018). 


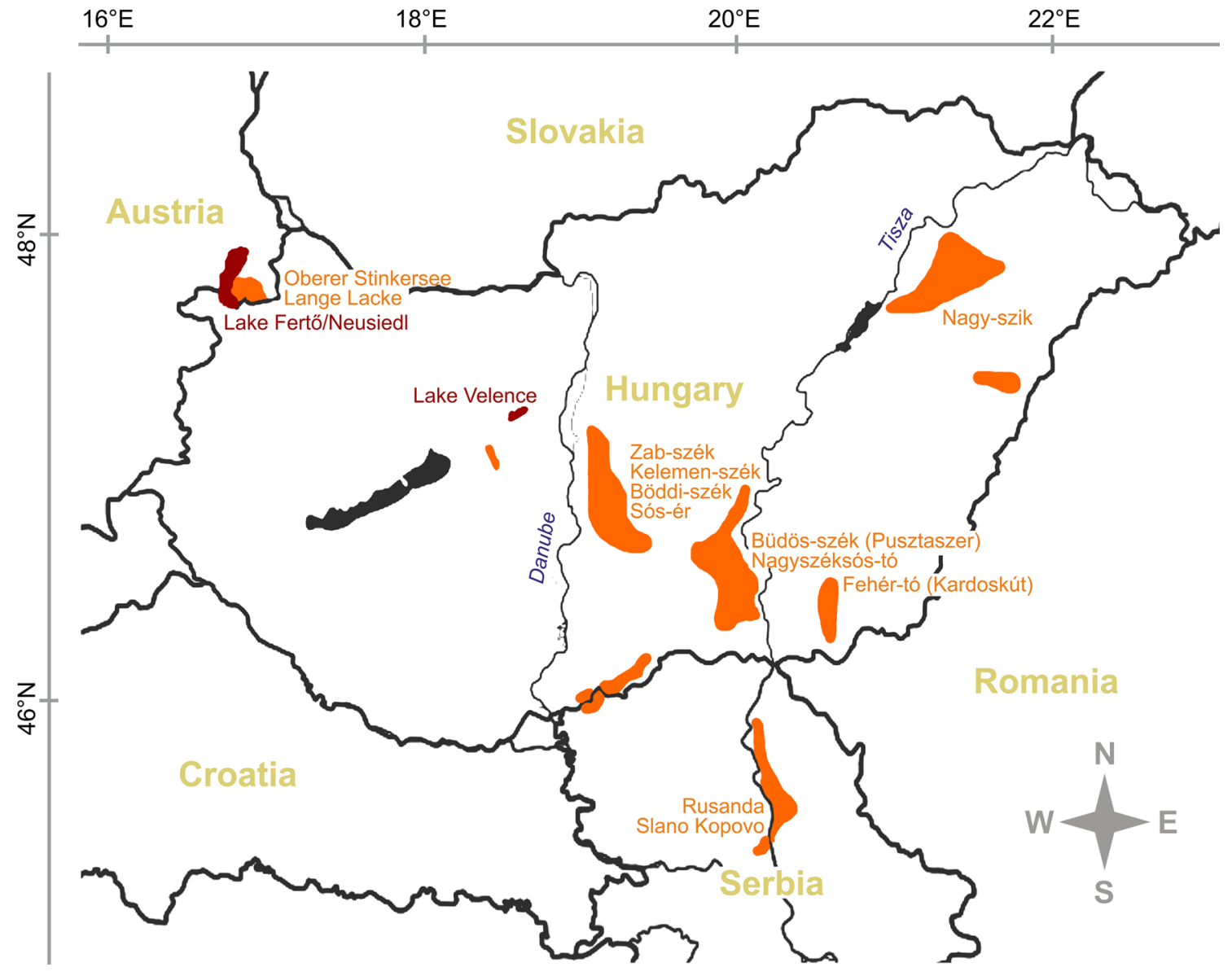

Fig. 1 Geographic location of soda lakes and pans in the Carpathian Basin. Soda lakes are marked in brown, and characteristic areas with soda pans are marked in orange. Selected examples of soda pans are also given for these areas. Based on the data of Boros et al. (2013, 2014, 2017)

Although studies on microbial communities started decades ago in this region, detailed information about the taxonomic composition of bacteria and small-sized algae became available with the introduction of cultivation-independent (particularly high-throughput DNA sequencing) methods. In this review, I summarize the current knowledge on the abundance, composition and ecology of microorganisms inhabiting these special alkaline aquatic habitats.

\section{Habitat types: the physical and chemical environment}

Lakes can be defined as continental water bodies that have a distinct shoreline habitat, but 'true' soda lakes are rarely found in the Carpathian Basin (Lake Fertő/Neusiedl and Lake Velence), since most of these endorheic aquatic ecosystems could be regarded as pans with extremely shallow water and no characteristic shoreline habitat (Figs. 1, 2; water depth 5-30 cm; area 3-20 ha; Boros et al. 2014). Precipitation, groundwater upwelling and evaporation (the annual amount of sunshine hours is $\sim 2000 \mathrm{~h}$; Boros et al. 2017; Kiss 1976) play the most important role in their water balance. In other words, hydrogeological and meteorological conditions determine their water regime. Due to these and the extreme shallowness of the pans, their salinity changes drastically throughout the year, but usually remains within the sub- and hyposaline range, within 1-20 g/L salinity values. This means that the salt content of these lakes and pans is typically less than half of that of seawater $(35 \mathrm{~g} / \mathrm{L})$; therefore, in some manner they are similar to 'brackish' waters (Boros et al. 2014, 2017; Table 1). The high number of windy days ( 120 days, Boros et al. 2017) in this plain area (a major part of the corresponding region is also called the Great Hungarian Plain) contributes to the continuous resuspension of sediment and the high inorganic turbidity of the water. Probably due to the high turbidity, the dynamic fluctuation of water level (and, therefore, lake area) and the high salinity, submerged macrophytes are sparse or absent from these lakes, while at the shores marshland vegetation may be present (Boros 1999; Boros et al. 2013). At some sites, expanded shoreline vegetation [mainly bayonet grass 

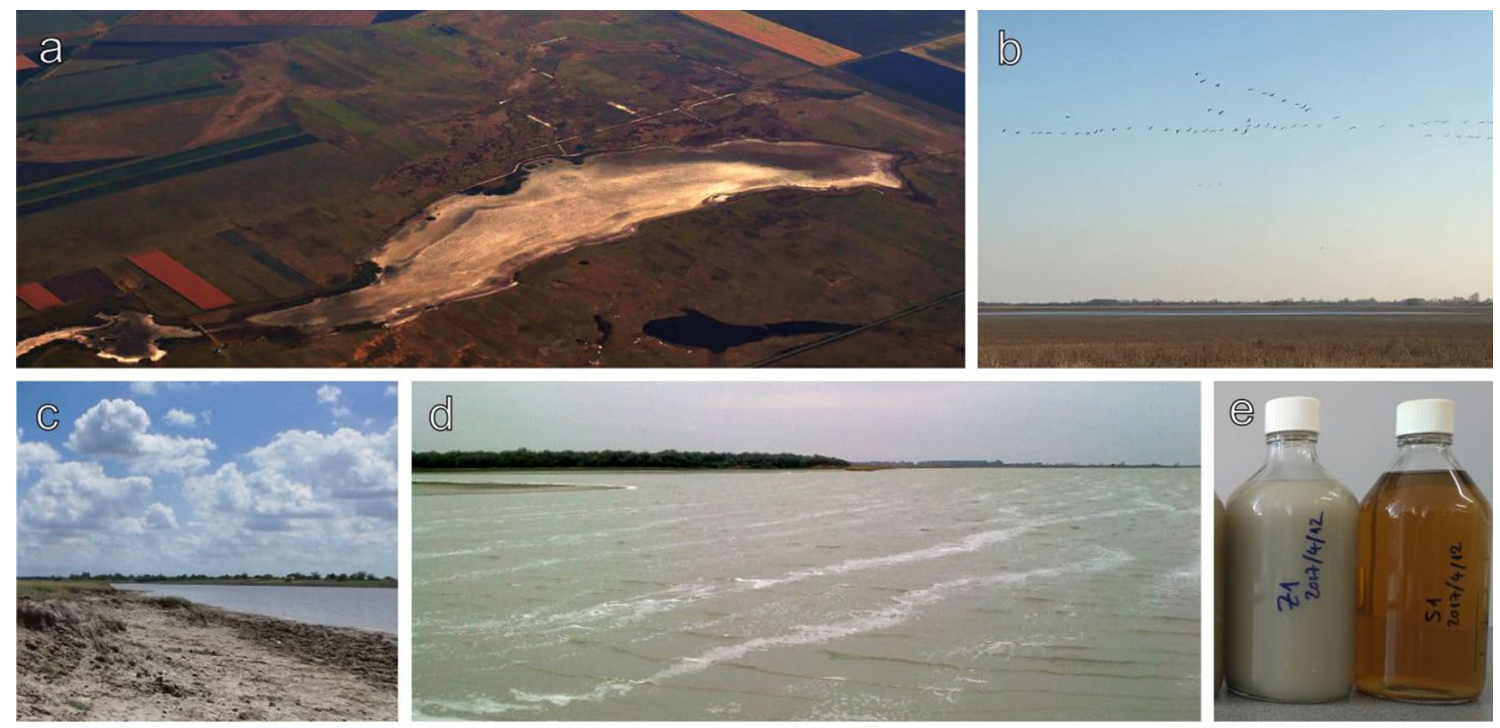

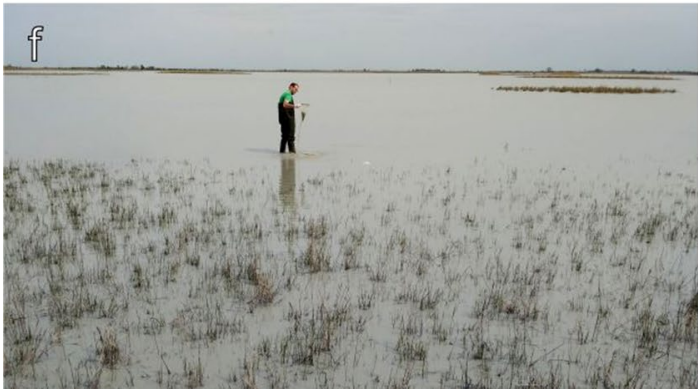

Fig. 2 Landscapes and important macroscopic characters of the soda pans in the Carpathian Basin. a Aerial view of a turbid soda pan (Fehér-tó near Kardoskút; photo: Erika Greipel). b Migrating birds flying over a soda pan [common crane (Grus grus) at Büdösszék near Pusztaszer]. c Shoreline of a turbid soda pan (Rusanda). d Waves generated by the strong wind in a turbid soda pan (Zab-szék).

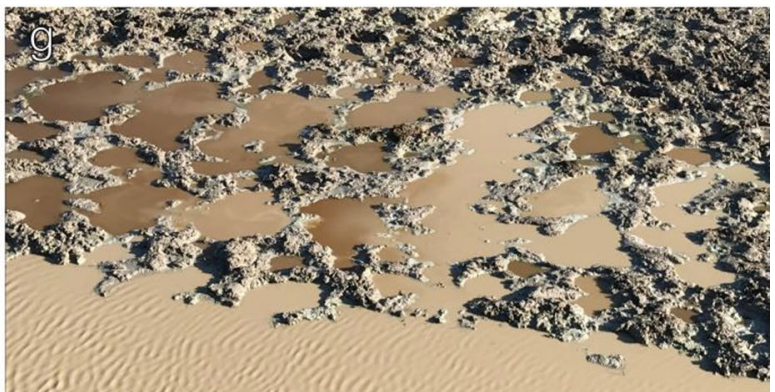

e Water samples collected from a turbid pan and a coloured soda pan (Zab-szék and Sós-ér). f Sample collection from a turbid soda pan (Kelemen-szék). g Mosaic of suspended and settled turbid water in buffalo footprints highlighting the high dissolved organic matter content (brown) of turbid-type soda pans (Nagyszéksós-tó). For the geographic location of these sites, see Fig. 1
Table 1 Physical and chemical characteristics of some soda lakes and pans of the Carpathian Basin

\begin{tabular}{llllll}
\hline & Lake Fertő/Neusiedl & Lake Velence & Zab-szék & Kelemen-szék & Sós-ér \\
\hline Type & Turbid & Turbid & Turbid & Turbid & Coloured \\
Area $\left(\mathrm{km}^{2}\right)$ & 309 & 24 & 1.82 & 1.90 & 0.03 \\
Depth $(\mathrm{cm})$ & $60-140$ & $50-150$ & $0-45^{*}$ & $0-40^{*}$ & $0-50^{*}$ \\
Secchi depth $(\mathrm{cm})$ & $2.5-30$ & $40-58$ & $0.5-7$ & $1-4$ & $1.5-25$ \\
$\mathrm{pH}$ & $8.9-9.3$ & $7.5-9.6$ & $8.9-10.2$ & $8.9-9.5$ & $8.3-10.1$ \\
Salinity $(\mathrm{g} / \mathrm{L})$ & $1.8-2.4$ & $0.7-2.6$ & $1.9-17.0$ & $1.4-11.2$ & $1.5-18.9$ \\
TSS $(\mathrm{mg} / \mathrm{L})$ & $20-260$ & $18-40$ & $150-8000$ & $700-2200$ & $3-340$ \\
TOC $(\mathrm{mg} / \mathrm{L})$ & $20-100$ & $20-25$ & $35-405$ & $40-70$ & $85-1200$ \\
TP $(\mathrm{mg} / \mathrm{L})$ & $0.02-0.1$ & $<0.01-1.7$ & $2.0-17.7$ & $3.1-3.3$ & $0.3-4.0$ \\
\hline
\end{tabular}

Based on data presented in Bell et al. (2018), Boros et al. (2008b, 2016, 2020), Borsodi et al. (2007), Bullerjahn et al. (2020), Somogyi et al. (2009, 2010), Szabó et al. (2020) and Szabó-Tugyi et al. (2019). If salinity data were not available, values were calculated from conductivity based on the equation of Boros et al. (2014). Physicochemical data are given for open water areas in the case of large soda lakes

*Astatic pan that could completely dry out
(Bolboschoenus maritimus) and common reed (Phragmites australis)] hinders sediment resuspension, which results in a lower inorganic suspended matter content in the water body (Table 1). Furthermore, groundwater and the decaying 
biomass of emergent macrophytes supply coloured dissolved organic matter (humic substances), which results in the polyhumic character of these pans (Boros et al. 2013, 2017, 2020).

Therefore, two different optical water types can be distinguished with the naked eye: the 'turbid' and the 'coloured' type (Boros et al. 2013, 2017; Fig. 2). Turbid-type waters have a characteristic greyish colour due to the high amount of suspended inorganic particles, while the brownish colour is a result of the high concentration of dissolved humic substances in the case of the coloured type. Both of the largest shallow soda lakes (Lake Fertő/Neusiedl and Lake Velence) in this region belong to the turbid type, and this type is more common also among the soda pans (Boros et al. 2013). However, it should be noted that these types are not always distinct categories; pans with intermittent character can also be found, and in the case of larger turbid lakes, the water of inner ponds within the reed belt resembles a coloured type soda pan (Boros et al. 2013; Dokulil 1979; Somogyi et al. 2010).

Taken together, these aquatic habitats can be considered as multiple extreme environments with stable alkaline $\mathrm{pH}$ and high water turbidity, and in the case of the soda pans, a fluctuating daily temperature (up to $28{ }^{\circ} \mathrm{C}$ difference) and intermittent (astatic) character (Boros et al. 2017; Kirschner et al. 2002). Furthermore, the concentration of several nutrients is also high throughout the year (e.g. the orthophosphate concentration is usually between 0.2 and $3.0 \mathrm{mg} / \mathrm{L}$, and the average of dissolved organic carbon is $90 \mathrm{mg} / \mathrm{L}$, in the range of 20-1000 mg/L; Boros et al. 2017, 2020; Table 1), which supports the growth of algae and bacteria. On the other hand, there is a relatively low N/P ratio in the water, partially due to the volatilization of ammonia under alkaline conditions (Boros et al. 2008b), which can significantly influence the microbial metabolic processes. Moreover, it should be noted that high local geographical diversity exists with respect to the physicochemical conditions, which can be explained by the differences in connectivity with groundwater, precipitation and other meteorological and geological features (Boros et al. 2017).

\section{Prokaryotes}

The abundance of planktonic bacteria is around $10^{6}-10^{7}$ cells $/ \mathrm{mL}$ and $10^{7}-10^{8}$ cells $/ \mathrm{mL}$ in the soda lakes and pans, respectively (Eiler et al. 2003; Kirschner et al. 2002; Szabó et al. 2020; Szabó-Tugyi et al. 2019; Vörös et al. 2008), and they belong mainly to the phyla Actinobacteria, Bacteroidetes and Proteobacteria (Bell et al. 2018; Bullerjahn et al. 2020; Szabó et al. 2017, 2020; Fig. 3). Archaea represent a minor fraction ( $\sim 10 \%$ on average) of the planktonic prokaryotic community (Szabó et al. 2017, 2020), probably due to the fact that these sites have only moderate salinity compared to other saline lakes in the world.

At lower taxonomic level, the uncultured groups acIIIA1, acSTL and acTH1 and the genera Nitriliruptor and Ilumatobacter are the most characteristic planktonic Actinobacteria in the shallow soda pans; their abundance can reach the highest values ever reported in the literature (up to $89 \%$; Szabó et al. 2020). Probably, these small-sized bacteria, which have a protective cell wall structure, are the survivors of grazing pressure during spring-summer (Szabó et al. 2017, 2020). The proportion of planktonic Betaproteobacteria (e.g. Limnohabitans and Hydrogenophaga), which are well-known planktonic bacteria in freshwaters (Newton et al. 2011), is the highest in periods with the lowest salinity (Szabó et al. 2020). Other important planktonic bacteria, like members of the classes Cytophagia, Flavobacteria and the order Rhodobacterales (Alphaproteobacteria), are associated with algal blooms (Bullerjahn et al. 2020; Korponai et al. 2019; Szabó et al. 2020). Based on shotgun metagenomic data, genes of the TonB receptor system, which is responsible for the uptake of phytoplankton-derived high molecular weight organic matter (Williams et al. 2013; Buchan et al. 2014), were the most abundant in the community gene pool (Szabó et al. 2017) in a turbid pan. In the rarely observable dual blooms, under a green algal surface layer, dense populations of purple bacteria composed of the genera Rhodobaca (Rhodobacterales), Thiorhodospira or Ectothiorhodospira (both Chromatiales, Gammaproteobacteria) can grow just above the sediment layer (Borsodi et al. 2013; Korponai et al. 2019). Most probably, such blooms can emerge if the weather is warm, sunny and calm (Korponai et al. 2019). Nevertheless, photoheterotrophic bacteria represent a significant fraction of the total planktonic bacterial community in the soda lakes and pans of the Carpathian Basin in general. Based on microscopic cell counts, the abundance of aerobic anoxygenic phototrophs is usually at the magnitude of $10^{6}-10^{7}$ cells $/ \mathrm{mL}$ and denotes $5-30 \%$ of heterotrophic bacteria (Szabó-Tugyi et al. 2019). According to the results of recent years, the previously frequently isolated Aeromonas, Pseudomonas and Bacillus species (Ács et al. 2003; Langó et al. 2002) denote only a negligible part of bacterioplankton (Fig. 3).

Remarkable diel changes in the planktonic microbial activity and abundance were also observed in the shallow soda pans, and external abiotic factors (diluting the effect of rainfall which decreases salinity, but also the grazing pressure and viral lysis, the wind-induced sediment resuspension, and daily fluctuations of temperature and irradiation) seem to have a regulating effect on them (Kirschner et al. 2002; Krammer et al. 2008). The generation time of bacteria in these environments can be as little as a few hours (Eiler et al. 2003; Krammer et al. 2008). Growth studies on planktonic bacterial isolates have shown that the type of 


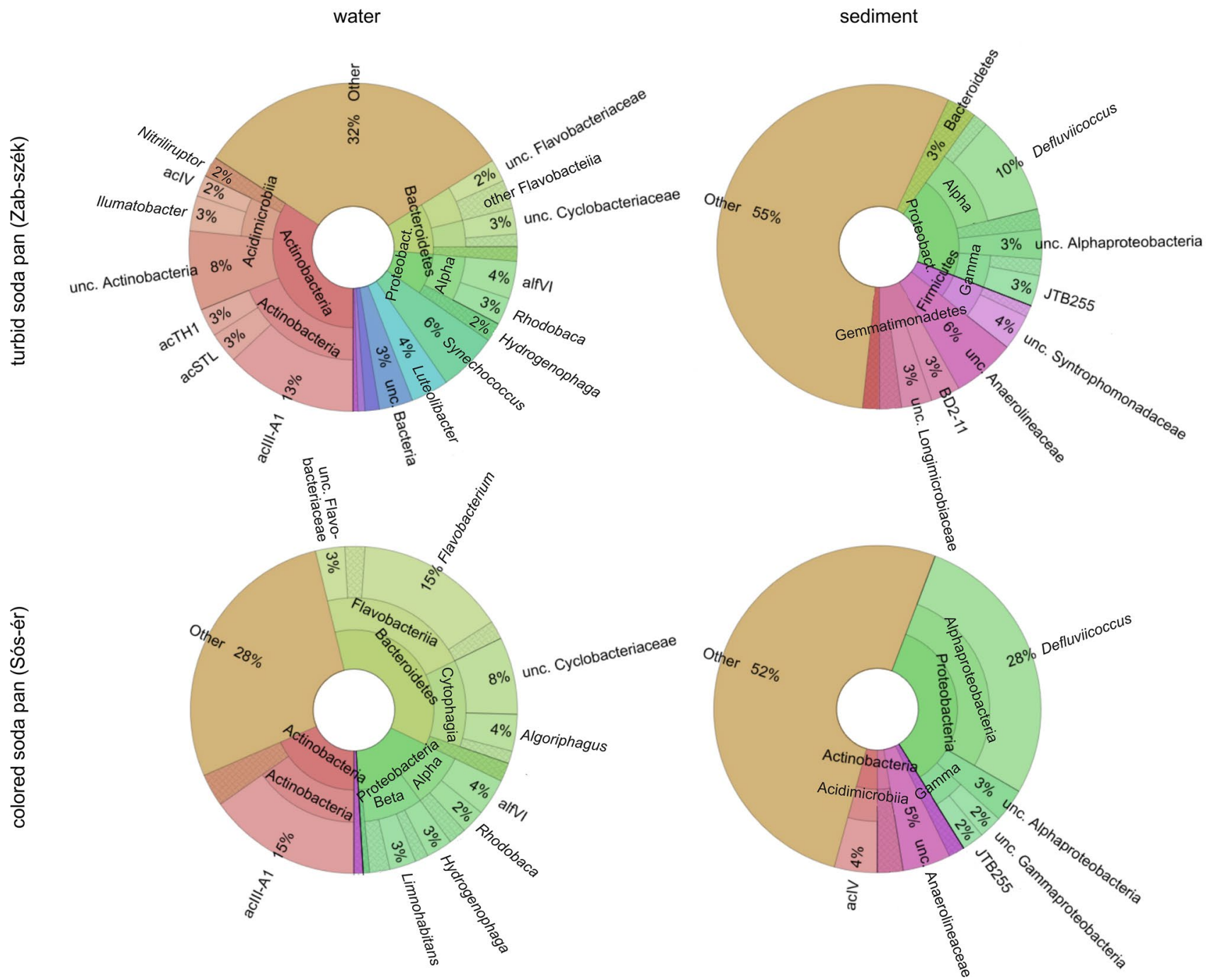

Fig. 3 Bacterial community composition of a turbid pan and a coloured soda pan from the Carpathian Basin. Based on the 16S rRNA gene amplicon sequencing data presented in Bedics et al. (2019) and

dominant anion determines the adaptation of prokaryotes, since strains isolated from soda pans grew better in media containing (hydrogen) carbonate than in media containing the same amount of chloride (Bedics et al. 2019).

Sediment bacterial communities of the soda pans in the Carpathian Basin are dominated by Proteobacteria, but the phyla Bacteroidetes, Actinobacteria, Gemmatimonadetes and Chloroflexi may also have significant contribution; and similarly to the bacterioplankton, remarkable differences are observable when comparing the turbid and the coloured pan (Bedics et al. 2019; Fig. 3). It seems that the abundant Defluviicoccus genus, which is capable of glycogen accumulation (Burow et al. 2007), has a special importance in the anaerobic biodegradation of organic material within the sediment. The number of lactate-utilizing sulphate-reducing bacteria was an order of magnitude higher in the reed
Szabó et al. (2020). Composite data are based on 16 and 13 planktonic samples in the case of Zab-szék and Sós-ér pans, respectively, and are based on 3-3 samples in the case of sediments

rhizosphere (i.e. in the vicinity of the macrophyte-derived organic carbon source) than in the sediment, and genera Desulfovibrio, Desulfotomaculum and Desulfobulbus have been detected in Lake Velence (Vladár et al. 2008). Furthermore, numerous moderately halophilic and alkaliphilic bacteria with a diverse metabolic profile have been isolated from the periphyton of reed (Borsodi et al. 2007; Rusznyák et al. 2008). The dominance of the phyla Proteobacteria (e.g. genera Rheinheimera, Hydrogenophaga, Agrobacterium) and Bacteroidetes (e.g. Flavobacterium) has been observed in these periphyton samples in cultivation-independent studies (Rusznyák et al. 2008).

Cyanobacteria are discussed in the section on algae of this review, since they perform photosynthesis with chlorophyll-a and, therefore, belong to the same functional group as eukaryotic algae; furthermore, in limnological practice, 
their amount is determined together with that of microalgae as 'bulk' chlorophyll-a concentration.

\section{Algae}

The high inorganic turbidity and the high concentration of humic compounds result in very low euphotic depth values in the soda lakes and pans of the Carpathian Basin ( 5-25 cm; Boros et al. 2017). Nonetheless, phytoplankton biomass is high (the chlorophyll-a concentration typically in the range of 5-200 $\mu \mathrm{g} / \mathrm{L}$ ), which means meso-, eu- and hypertrophic conditions; most of the shallow soda pans are hypertrophic (Boros et al. 2017; Somogyi et al. 2009, 2010, 2017).

At these sites, pico-sized algae $(<3 \mu \mathrm{m}$; APP, photoautotrophic picoplankton or picophytoplankton) typically contribute to the total phytoplankton biomass with $50-100 \%$, and their abundance is around $10^{6}-10^{7}$ cells $/ \mathrm{mL}$, but it can reach the highest values ever reported (up to $10^{8}$ cells $/ \mathrm{mL}$; Keresztes et al. 2010; Somogyi et al. 2009, 2017; Fig. 4). APP are the most predominant in pans where the inorganic turbidity is higher than $50 \mathrm{mg} / \mathrm{L}$, since it is hypothesized that in these turbid waters, the low underwater light intensity (which is circumvented with the high surface-to-volume ratio of the cells; Raven 1998) and the reduced grazing pressure have a promotional effect on their ecological success (Somogyi et al. 2017). In general, within this group, picocyanobacteria dominate when the water temperature is higher than $15^{\circ} \mathrm{C}$, while eukaryotic algae are the main APP members during the cooler period of the year (Somogyi et al. 2009; Fig. 4). Photosynthetically active algae (APP and nanoplankton) were recently detected even in the ice of Lake Fertő/Neusiedl, with an abundance of around $10^{4}$ APP cells/mL (Bullerjahn et al. 2020). Only phycocyanin-rich picocyanobacteria (with a greenish colour) may prevail at these sites (Felföldi et al. 2009; Somogyi et al. 2009, 2016), since the high turbidity and the high amount of coloured dissolved organic matter create a 'red shift' in the underwater light spectrum (Stomp et al. 2007; Vörös et al. 1998).

The picocyanobacterial community in these lakes and pans is dominated by small coccoid solitary cells (Somogyi et al. 2009, 2010), which belong to various non-marine Synechococcus/Cyanobium groups of the picophytoplankton clade sensu Urbach et al. (1998) (Bell et al. 2018; Felföldi et al. 2009, 2011; Szabó et al. 2020). In the case of Lake Fertő/Neusiedl, most picocyanobacteria belong to the Cyanobium gracile cluster (Group A) of the above-mentioned clade (Somogyi et al. 2010). Planktonic eukaryotic picoalgae are composed of members of the genera Choricystis and
Fig. 4 Seasonal changes in the picophytoplankton community in a turbid soda pan. Amplicon pyrosequencing data combined with microscopic cell counts of picocyanobacteria and eukaryotic picoalgae (Zab-szék pan). Analysis based on the data presented in Szabó et al. (2020). For the phylogenetic position of each OTU, see also Szabó et al. (2020)
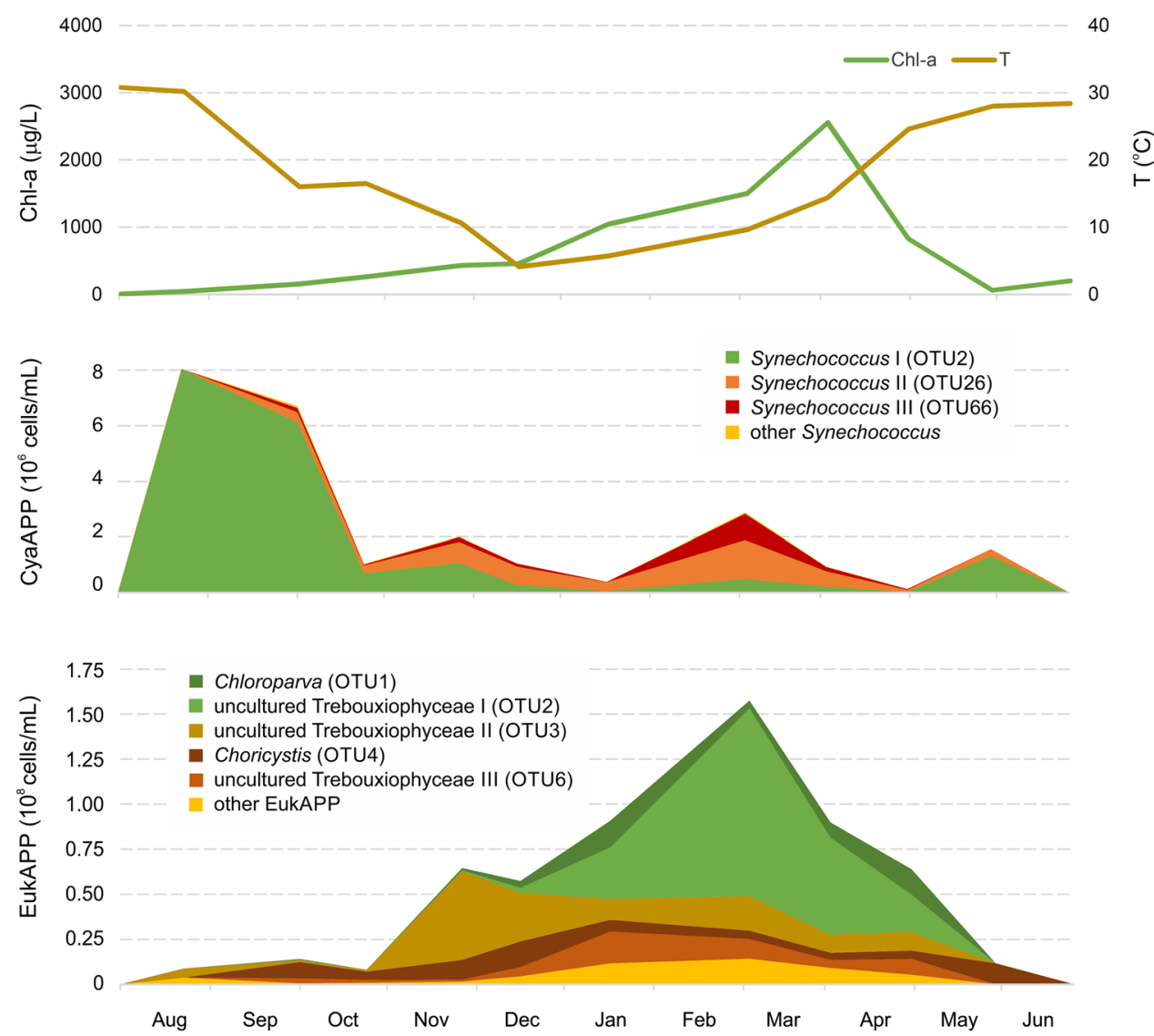
Chloroparva and other uncultured green algal (mainly trebouxiophycean) taxa, which have characteristic seasonal dynamics (Bell et al. 2018; Somogyi et al. 2011, 2016; Fig. 4).

Regarding the composition of larger planktonic algae in the soda lakes of the Carpathian Basin, Cyanobacteria (Planktothrix, Microcystis, this latter often causes toxic bloom in Lake Velence), green algae (Monoraphidium), diatoms and euglenids are characteristic in the open turbid water, while in the coloured inner ponds, Cryptophyta (Rhodomonas, Cryptomonas), Dinophyta (Peridinium) and diatoms (Campylodiscus, Cyclotella, mainly meroplanktonic species) are the most common groups (Ács et al. 2003; Bell et al. 2018; Bullerjahn et al. 2020; Dokulil et al. 2014; Padisák 1992; Padisák and Dokulil 1994; Somogyi et al. 2010, 2016).

In the coloured shallow pans, during summer, the cyanobacterial genera Aphanizomenon and Anabaenopsis may form even blooms (Boros et al. 2013). In the turbid soda pans, nanoplanktonic eukaryotic algae (e.g. Cryptomonas) are only rarely observed due to the dominance of APP, while in the coloured pans euglenids (Euglena, Phacus) and chlamydomonads (Carteria, Chlamydomonas) may even present with biomass values as high as 3-30 mg/L (Gavrilović et al. 2018; Szabó et al. 2020). Occasionally, dual planktonic blooms can be observed in the shallow pans with an upper layer dominated by a green alga (Oocystis submarina) and a deeper layer with purple bacteria (Borsodi et al. 2013; Korponai et al. 2019). Contrary to this, a winter bloom under the snow and ice cover was composed of several uncultured green algal genotypes with pico-sized cells (Pálffy et al. 2014). Neuston blooms of euglenids and the green alga Nautococcus have also been reported (Boros et al. 2013).

In the shallow nearshore areas of the pans, filamentous green algae (e.g. Cladophora, Oedogonium and Gongrosira) or members of the class Xanthophyceae (e.g. Tribonema and Vaucheria) may develop and grow in the entire water body. If the water level decreases, these algal mats dry, and the result is irregular paper scrap-like structures, the so-called meteor paper (Boros et al. 2013; Fehér 2010; Kiss 1971, 1976). Benthic algal mats of nitrogen-fixing Nodularia (Cyanobacteria) species can be observed, but only when the water depth is extremely shallow $(<5 \mathrm{~cm})$ and sufficient light reaches the sediment surface, while in the deeper regions of the turbid pans, the role of benthic algae is negligible (Boros et al. 2013; Vörös and Boros 2010). The benthic diatom communities of the soda pans are mainly composed of Nitzschia and Navicula species, also including fast-moving species (Gavrilović et al. 2018; further details can be found in the beautifully illustrated paper of StengerKovács and Lengyel 2015).

The periphyton community of Lake Fertő/Neusiedl and Lake Velence is dominated by diatoms (mainly Pennales, like Achnanthes, Nitzschia, Synedra, Fragilaria, Gomphonema and Cymbella; Ács et al. 2003; Buczkó 1989; Buczkó and Ács 1998).

\section{Protists, viruses and fungi}

Most heterotrophic nanoflagellate (HNF) species are relatively small $(\sim 5-10 \mu \mathrm{m}$ in diameter), and they are supposed to be the main protozoan grazers of bacteria and picophytoplankton (Weisse 1993). Using classical microscopy, it is relatively complicated to enumerate and identify HNFs from these turbid environments; therefore, only a few studies have been conducted to date. However, the abundance of HNFs may be around $10^{4}-10^{5}$ cells $/ \mathrm{mL}$ (Krammer et al. 2008), and as it was revealed recently by an 18S rRNA gene-targeted high-throughput sequencing study, the most important flagellate genera in the soda pans of the Carpathian Basin are Spumella, Jakoba, Ochromonas and Andalucia (Márton et al. 2019).

Ciliates were studied intensively at these sites decades ago (mainly sessile forms; Gelei 1950; Stiller 1963; Szabó 1999), several novel species and genera have been described, and a diverse community was revealed (with genera Epistylis, Vorticella and Maryna), but unfortunately no detailed recent data on their abundance and composition are available. Ciliates have approximately one magnitude larger cell size than the HNF species $(\sim 50-200 \mu \mathrm{m}$ in diameter) and possibly contribute to a lesser extent to the planktonic food web, since Krammer et al. (2008) found no ciliates in the water samples collected from small soda pans near Lake Fertő/Neusiedl, which supported that planktonic ciliates are a negligible fraction of the microbial community and their role in benthic habitats may be much more pronounced.

According to the above-mentioned 18S rRNA genebased amplicon sequencing study (Márton et al. 2019), fungi can, in some cases, be important members of the planktonic community. Due to their saprophytic lifestyle, alkalitolerant fungi may contribute also to the mineralization of organic matter, e.g. after the collapse of summer algal bloom or during the decline of zooplankton populations.

Virological studies on these environments are, similarly, very scarce. Bacteriophages, mainly Caudovirales, were detected by Szabó et al. (2017) in the plankton of a turbid pan, while members of Phycodnaviridae (viruses that infect algae; Larsen et al. 2008) were reported from Lake Velence (Bell et al. 2018). The number of viral particles was estimated to be around $10^{8}-10^{9} / \mathrm{mL}$ in the water of some soda pans in the Carpathian Basin (Krammer et al. 2008). 


\section{Food webs}

A schematic food-web structure for a soda pan is shown in Fig. 5.

Birds have dual roles (net importers or net exporters) on the trophic food web of these pans: some species (e.g. the herbivorous geese; e.g. Anser species) supply the water with a high amount of allochthonous nutrients through their excrements, while others (e.g. Anas species) feed on the large populations of zooplankton (Boros et al. 2006, 2008a, b, 2016). The contribution of birds to the external nutrient load was estimated to be 50,35 and $70 \%$ in the case of organic carbon, nitrogen and phosphorous, respectively (Boros et al. 2008a, b). Furthermore, the continuous mixing by the wind does not allow the bird faeces to settle down to the bottom of the pans, and therefore, they can provide a nutrient supply directly to the planktonic organisms. The naturally high concentration of nutrients results in eutrophic or, in many cases, even hypertrophic conditions, which, in this case, is called guanotrophication (Boros et al. 2016).

In general, the growth of phytoplankton and heterotrophic bacteria is supplied with nutrients from external sources (bird excrements and groundwater) and from decomposing shoreline macrophytes (Boros et al. 2008b, 2016, 2020; Dokulil et al. 2014; Vörös et al. 2008). On decaying reed, the periphyton and bacterial community was different compared with 'healthy' green reed (Ács et al. 2008; Buczkó and Ács 1998), and bacteria with urease activity and capable of biopolymer utilization were also isolated (Rusznyák et al. 2008), which indicates the role of microorganisms in the mineralization of organic matter originating from shoreline vegetation and from birds. Heterotrophic processes in plankton are much more pronounced than autotrophic ones (net heterotrophic systems; Boros et al. 2016; Vörös et al. 2008), and alkaline $\mathrm{pH}$ was also reported to having an accelerating effect on organic matter degradation (Krachler et al. 2009). So, it should be emphasized that contrary to the fact that soda pans are, in many cases, hypertrophic (even with visible blooms, e.g. Korponai et al. 2019; Pálffy et al. 2014), heterotrophic activity is more significant.

The most important consumers of bacteria and algae are probably HNFs and microcrustaceans, while a fraction of the planktonic heterotrophic bacteria can be particle attached, which may protect cells against grazing in turbid pans (Koblížek 2015; Szabó-Tugyi et al. 2019).

Fish are usually absent from soda pans due to the astatic character of these pans, which results in the high abundance of zooplankton (Boros et al. 2006; Horváth et al. 2013) and a relatively strong top-down control of bacterio- and phytoplankton (Szabó et al. 2020). Therefore, the main consumers of zooplankton in these soda pans are filter feeder bird species and not fish. Some of the organic carbon and nutrients can be released from the system even through emerging insects and dust transferred by the wind from the dried-up lake bottom (Boros et al. 2013). However, if conditions are appropriate (e.g. there is no desiccation through subsequent years), fish populations [Prussian carp (Carassius gibelio) or stone moroko (Pseudorasbora parva)] may survive (Boros et al. 2013). Furthermore, in the case of large soda lakes (Lake Fertő/Neusiedl and Lake Velence), a diverse fish community is continuously present (due to the constantly low salinity values and the artificially set relatively high water level); fishing is allowed, and it is a popular activity at these sites (Borics et al. 2016).

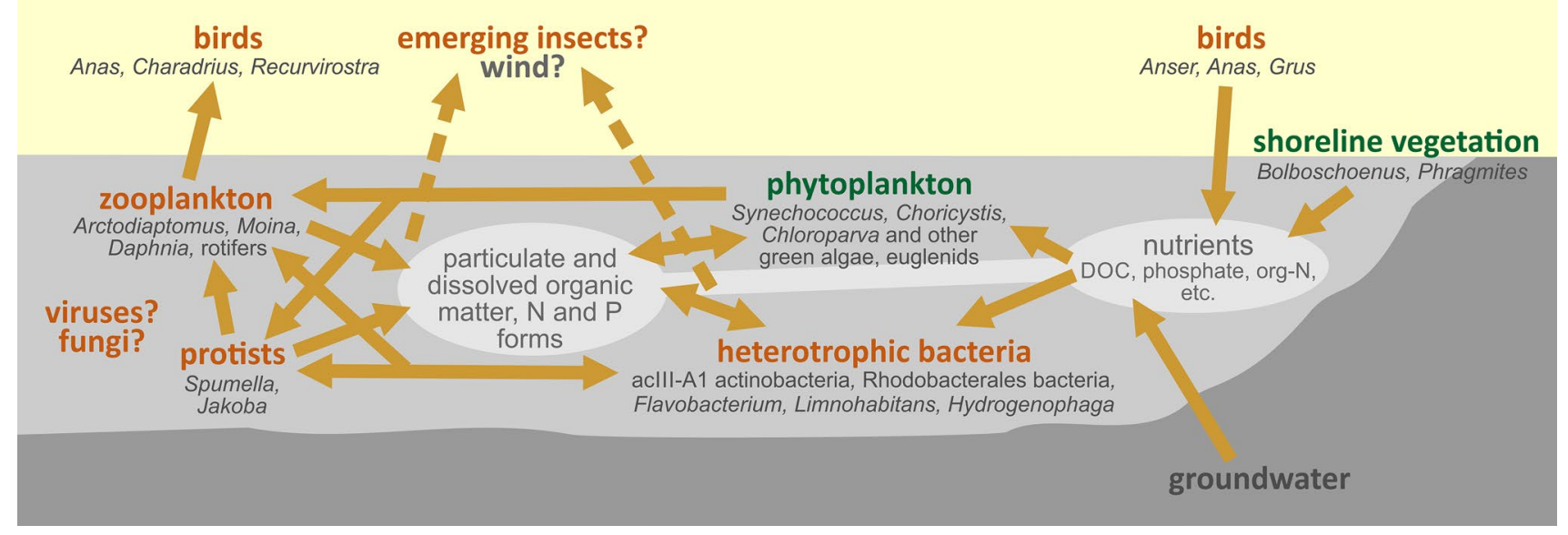

Fig. 5 Schematic planktonic food web structure of intermittent (astatic) soda pans in the Carpathian Basin. Arrows show the main flow directions of organic carbon and nutrients. For the sake of simplicity, only major food web components are shown. Autotrophic organisms are marked with green, heterotrophs with brown letters. Characteristic genera are given for each group 
For additional information about aquatic birds, shoreline vegetation and the composition and ecology of zooplankton communities, see Boros et al. (2013, 2016), Dokulil and Herzig (2009), Horváth et al. (2013, 2014, 2016, 2019) and Tóth et al. (2014).

\section{Conclusions for future biology}

The large number of novel taxa described from various habitats of soda lakes and pans of the Carpathian Basin (Table 2) indicates that these sites are important sources of unexplored biodiversity. It has been argued that biodiversity is generally higher in soda lakes compared with other continental saline lakes due to their relatively lower salinity (Grant 2004). Bacteria isolated from these habitats may be important sources of bioactive molecules and enzymes in the future, as detergent additives originating from soda lakes are already applied to help domestic and industrial washing processes (Grant 2004; Kalwasińska et al. 2018; Rothschild and Mancinelli 2001). Microalgae inhabiting these sites may be applied in biofuel production and wastewater treatment and may represent important natural sources for the cosmetic and food industries (Aravantinou et al. 2016; Khan et al. 2018; Selvarajan et al. 2015). Furthermore, these sites also have balneotherapeutic potential; the only existing example in this region is the medical centre by Lake Rusanda (Melenci, Serbia).

Based on current knowledge, it seems that mainly temperature, salinity, turbidity and grazing pressure regulate community composition and the abundance of individual microbial groups in the soda lakes and pans of the Carpathian Basin (Somogyi et al. 2009; Szabó et al. 2020), but the external nutrient load from birds also has a significant impact on the ecological processes (Boros et al. 2016; Vörös et al. 2008). The unusually high dissolved organic carbon and nutrient content results in hypertrophic conditions and a net heterotrophic system (Boros et al. 2008b, 2020; Somogyi et al. 2009; Vörös et al. 2008), where zooplankton have a special importance in the control of microbial plankton (due to the lack of fish in most of these habitats; Boros et al. 2013; Horváth et al. 2013; Szabó et al. 2020). The dual role of birds and special environmental conditions (high $\mathrm{pH}$, low transparency, moderate salinity with special ionic composition) add further unique features to these protected sites (Boros et al. 2006, 2013, 2014, 2016, 2017).

On the other hand, the processes observed in these multiple extreme aquatic habitats can be regarded as analogues of global environmental problems, e.g. (1) due to their shallowness, these sites are very sensitive to changes of meteorological conditions; (2) due to rising sea levels, moderately saline environments are expected to become more common if saltwater intrudes into coastal freshwater habitats; (3) increased evaporation is expected to result in a shift in many lakes from freshwater to saline conditions (Jeppesen et al. 2015); and (4) the growing human population creates environments with a high concentration of nutrients with the introduction of wastewaters to surface waters.

Finally, it should be noted that a significant fraction of soda pans has disappeared ( $\sim 80 \%$ habitat loss) in the region due to human activities during the last 60 years (Boros et al. 2013), which has resulted in notable species loss (Horváth et al. 2019). However, ongoing management, monitoring and protection actions (see, e.g. www.boddi.hu; www.horto bagyte.hu) are promising trends to save these unique aquatic habitats for the future.

Table 2 Examples of new bacterial and algal species recently described from the soda lakes and pans of the Carpathian Basin

\begin{tabular}{|c|c|c|c|}
\hline \multirow[t]{2}{*}{ Species name } & \multicolumn{2}{|l|}{ Isolation source } & \multirow[t]{2}{*}{ Reference } \\
\hline & Site & Habitat & \\
\hline \multicolumn{4}{|l|}{ Bacteria } \\
\hline Arundinibacter roseus (gen. nov., sp. nov.) & Lake Fertő/Neusiedl & Lake water (inner pond) & Szuróczki et al. (2019) \\
\hline Bacillus alkalisediminis (sp. nov.) & Kelemen-szék (KNP) & Upper sediment layer & Borsodi et al. (2011) \\
\hline Bacillus aurantiacus (sp. nov.) & Kelemen-szék (KNP) & Upper sediment layer & Borsodi et al. (2008) \\
\hline Cellulomonas phragmiteti (sp. nov.) & Kelemen-szék (KNP) & Reed periphyton & Rusznyák et al. (2011) \\
\hline Nesterenkonia pannonica (sp. nov.) & Böddi-szék (KNP) & Lake water & Borsodi et al. (2017b) \\
\hline Nitrincola alkalilacustris (sp. nov.) & Zab-szék (KNP) & Lake water & Borsodi et al. (2017a) \\
\hline Nitrincola schmidtii (sp. nov.) & Unnamed pan (KNP) & Lake water & Borsodi et al. (2017a) \\
\hline Pannonibacter phragmitetus (gen. nov., sp. nov.) & Lake Fertő/Neusiedl & Decomposing reed rhizome & Borsodi et al. (2003) \\
\hline Phragmitibacter flavus (gen. nov., sp. nov.) & Lake Fertő/Neusiedl & Lake water from a reed-covered area & Szuróczki et al. (2020) \\
\hline \multicolumn{4}{|l|}{ Algae } \\
\hline Chloroparva pannonica (gen. nov., sp. nov.) & Böddi-szék (KNP) & Lake water & Somogyi et al. (2011) \\
\hline
\end{tabular}

The term 'sp. nov.' in parentheses indicates that the taxon was described as a new species, while 'gen. nov.' stands for a new genus described for the first time from these sites. Abbreviation: $K N P$-Kiskunság National Park, Hungary 
Remember the proverb: Varietas delectat (Cicero).

Acknowledgements Open access funding provided by Eötvös Loránd University. I am thankful to Attila Szabó for performing data analysis, and to him and Emil Boros, Lajos Vörös and Zsuzsanna Márton for their invaluable comments on the manuscript, furthermore to all the co-authors of my previous soda lake-related publications, especially to Boglárka Somogyi. I am also thankful to Susann Pihl for proofreading the manuscript.

Funding This work was financially supported by the National Research, Development and Innovation Office, Hungary (Grant No. K116275), and by the János Bolyai Research Scholarship of the Hungarian Academy of Sciences (Grant No. BO/00837/20/8).

\section{Compliance with ethical standards}

Conflict of interest The author declares that there is no conflict of interest.

Open Access This article is licensed under a Creative Commons Attribution 4.0 International License, which permits use, sharing, adaptation, distribution and reproduction in any medium or format, as long as you give appropriate credit to the original author(s) and the source, provide a link to the Creative Commons licence, and indicate if changes were made. The images or other third party material in this article are included in the article's Creative Commons licence, unless indicated otherwise in a credit line to the material. If material is not included in the article's Creative Commons licence and your intended use is not permitted by statutory regulation or exceeds the permitted use, you will need to obtain permission directly from the copyright holder. To view a copy of this licence, visit http://creativecommons.org/licenses/by/4.0/.

\section{References}

Ács É, Borsodi AK, Makk J, Molnár P, Mózes A, Rusznyák A, Reskóné MN, Kiss KT (2003) Algological and bacteriological investigations on reed periphyton in Lake Velencei, Hungary. Hydrobiologia 506:549-557

Ács É, Borsodi AK, Kiss É, Kiss KT, Szabó KÉ, Vladár P, Várbíró G, Gy Z (2008) Comparative algological and bacteriological examinations on biofilms developed on different substrata in a shallow soda lake. Aquat Ecol 42:521-531

Aravantinou AF, Frementiti A, Manariotis ID (2016) Post treatment of primary and secondary effluent by Chlorococcum sp. Environ Proc 3:35-45

Bedics A, Csitári B, Szabó A, Székely AJ, Boros E, Felföldi T (2019) Bacterial communities and their salt tolerance in different type of soda pans of the Kiskunság National Park, Hungary. Hidrol Közl 99:36-43 (in Hungarian with English abstract)

Bell TAS, Sen-Kilic E, Felföldi T, Vasas G, Fields MW, Peyton BM (2018) Microbial community changes during a toxic cyanobacterial bloom in an alkaline Hungarian lake. Antonie Van Leeuwenhoek 111:2425-2440

Borics G, Ács É, Boda P, Boros E, Erôs T, Grigorszky I, Kiss KT, Lengyel Sz, Reskóné NM, Somogyi B, Vörös L (2016) Water bodies in Hungary - an overview of their management and present state. Hung J Hydrol 96:57-67

Boros E (1999) Ecological state of sodic water bodies in Hungary. Acta Biol Debr Oecol Hung 9:13-80 (in Hungarian with English abstract)
Boros E, Kolpakova M (2018) A review of the defining chemical properties of soda lakes and pans: an assessment on a large geographic scale of Eurasian inland saline surface waters. PLoS ONE 13:e0202205

Boros E, Banfi S, Forró L (2006) Anostracans and microcrustaceans as potential food sources of waterbirds on sodic pans of the Hungarian plain. Hydrobiologia 567:341-349

Boros E, Forró L, Gere G, Kiss O, Vörös L, Andrikovics S (2008a) The role of aquatic birds in the regulation of trophic relationships of continental soda pans in Hungary. Acta Zool Acad Sci Hung 54(S1):189-206

Boros E, Nagy T, Pigniczki C, Kotymán L, Balogh KV, Vörös L (2008b) The effect of aquatic birds on the nutrient load and water quality of soda pans in Hungary. Acta Zool Acad Sci Hung 54(S1):207-224

Boros E, Ecsedi Z, Oláh J (2013) Ecology and management of soda pans in the Carpathian Basin. Hortobágy Természetvédelmi Egyesület, Balmazújváros

Boros E, Horváth H, Wolfram G, Vörös L (2014) Salinity and ionic composition of the shallow astatic soda pans in the Carpathian Basin. Ann Limnol Int J Limnol 50:59-69

Boros E, Pigniczki C, Sápi T, Balogh KV, Vörös L, Somogyi B (2016) Waterbird-mediated productivity of two soda pans in the Carpathian Basin in Central Europe. Waterbirds 39:388-401

Boros E, Balogh KV, Vörös L, Horváth Z (2017) Multiple extreme environmental conditions of intermittent soda pans in the Carpathian Basin (Central Europe). Limnologica 62:38-46

Boros E, Balogh KV, Csitári B, Vörös L, Székely AJ (2020) Macrophytes and groundwater drive extremely high organic carbon concentration of soda pans. Freshw Biol. https://doi. org/10.1111/fwb.13521

Borsodi AK, Micsinai A, Kovács G, Tóth E, Schumann P, Kovács AL, Böddi B, Márialigeti K (2003) Pannonibacter phragmitetus gen. nov., sp. nov., a novel alkalitolerant bacterium isolated from decomposing reed rhizomes in a Hungarian soda lake. Int J Syst Evol Microbiol 53:555-561

Borsodi AK, Rusznyák A, Molnár P, Vladár P, Reskóné MN, Tóth EM, Sipos R, Gedeon G, Márialigeti K (2007) Metabolic activity and phylogenetic diversity of reed (Phragmites australis) periphyton bacterial communities in a Hungarian shallow soda lake. Microb Ecol 53:612-620

Borsodi AK, Márialigeti K, Szabó G, Palatinszky M, Pollák B, Kéki Z, Kovács AL, Schumann P, Tóth EM (2008) Bacillus aurantiacus sp. nov., an alkaliphilic and moderately halophilic bacterium isolated from Hungarian soda lakes. Int J Syst Evol Microbiol $58: 845-851$

Borsodi AK, Pollák B, Kéki Z, Rusznyák A, Kovács AL, Spröer C, Schumann P, Márialigeti K, Tóth EM (2011) Bacillus alkalisediminis sp. nov., an alkaliphilic and moderately halophilic bacterium isolated from sediment of extremely shallow soda ponds. Int J Syst Evol Microbiol 61:1880-1886

Borsodi AK, Knáb M, Czeibert K, Márialigeti K, Vörös L, Somogyi B (2013) Planktonic bacterial community composition of an extremely shallow soda pond during a phytoplankton bloom revealed by cultivation and molecular cloning. Extremophiles 17:575-584

Borsodi AK, Korponai K, Schumann P, Spröer C, Felföldi T, Márialigeti K, Szili-Kovács T, Tóth E (2017a) Nitrincola alkalilacustris sp. nov. and Nitrincola schmidtii sp. nov., alkaliphilic bacteria isolated from soda pans, and emended description of the genus Nitrincola. Int J Syst Evol Microbiol 67:5159-5164

Borsodi AK, Szili-Kovács T, Schumann P, Spröer C, Márialigeti K, Tóth E (2017b) Nesterenkonia pannonica sp. nov., a novel alkaliphilic and moderately halophilic actinobacterium. Int J Syst Evol Microbiol 67:4116-4120 
Buchan A, LeCleir GR, Gulvik CA, González JM (2014) Master recyclers: features and functions of bacteria associated with phytoplankton blooms. Nat Rev Microbiol 12:686-698

Buczkó K (1989) About the spatial distribution of the algae and the quantitative development of periphyton in the Hungarian part of Lake Fertő (Neusiedler See). BFB-Bericht 71:111-124

Buczkó K, Ács É (1998) Comparison of succession of reed periphyton in a degraded and in an undisturbed part of a shallow lake (Lake Velencei, Hungary, Central Europe). Int Ver Theor 26:1674-1676

Bullerjahn GS, McKay RML, Bernát G, Prášil O, Vörös L, Pálffy K, Tugyi N, Somogyi B (2020) Community dynamics and function of algae and bacteria during winter in central European great lakes. $\mathrm{J}$ Great Lakes Res. https://doi.org/10.1016/j.jglr.2019.07.002

Burow LC, Kong Y, Nielsen JL, Blackall LL, Nielsen PH (2007) Abundance and ecophysiology of Defluviicoccus spp., glycogen-accumulating organisms in full-scale wastewater treatment processes. Microbiology 153:178-185

Dokulil M (1979) Optical properties, colour and turbidity. In: Löffler $\mathrm{H}$ (ed) Neusiedlersee-limnology of a shallow lake in Central Europe. Dr. W. Junk Publishers, The Hague-Boston-London, pp 151-162

Dokulil MT, Herzig A (2009) An analysis of long-term winter data on phytoplankton and zooplankton in Neusiedler See, a shallow temperate lake, Austria. Aquat Ecol 43:715-725

Dokulil MT, Herzig A, Somogyi B, Vörös L, Donabaum K, May L, Nõges T (2014) Winter conditions in six European shallow lakes: a comparative synopsis. Est J Ecol 63:111-129

Eiler A, Farnleitner AH, Zechmeister TC, Herzig A, Hurban C, Wesner W, Krachler R, Velimirov B, Kirschner AK (2003) Factors controlling extremely productive heterotrophic bacterial communities in shallow soda pools. Microb Ecol 46:43-54

Fehér G (2010) The algal flora of white and brown soda ponds of Kiskunság area. Acta Biol Debr Oecol Hung 22:121-137 (in Hungarian with English abstract)

Felföldi T, Somogyi B, Márialigeti K, Vörös L (2009) Characterization of photoautotrophic picoplankton assemblages in turbid, alkaline lakes of the Carpathian Basin (Central Europe). J Limnol 68:385-395

Felföldi T, Somogyi B, Márialigeti K, Vörös L (2011) Notes on the biogeography of non-marine planktonic picocyanobacteria: reevaluating novelty. J Plankton Res 33:1622-1626

Gavrilović B, Ćirić M, Vesić A, Vidaković D, Novaković B, Živanović M (2018) Biodiversity overview of soda pans in the Vojvodina region (Serbia). J Geogr Inst Cvijic 68:195-214

Gelei J (1950) Die Marynidae der Sodagewässer in der Nähe von Szeged. Hidrol Közl 30:107-119 (in German)

Grant WD (2004) Introductory chapter: half a lifetime in soda lakes. In: Ventosa A (ed) Halophilic microorganisms. Springer, Berlin, pp 17-31

Hammer UT (1986) Saline lake ecosystems of the world. Springer, New York

Horváth Z, Vad CF, Vörös L, Boros E (2013) The keystone role of anostracans and copepods in European soda pans during the spring migration of waterbirds. Freshw Biol 58:430-440

Horváth Z, Vad CF, Tóth A, Zsuga K, Boros E, Vörös L, Ptacnik R (2014) Opposing patterns of zooplankton diversity and functioning along a natural stress gradient: when the going gets tough, the tough get going. Oikos 123:461-471

Horváth Z, Vad CF, Ptacnik R (2016) Wind dispersal results in a gradient of dispersal limitation and environmental match among discrete aquatic habitats. Ecography 39:726-732

Horváth Z, Ptacnik R, Vad CF, Chase JM (2019) Habitat loss over six decades accelerates regional and local biodiversity loss via changing landscape connectance. Ecol Lett 22:1019-1027
Jeppesen E, Brucet S, Naselli-Flores L, Papastergiadou E, Stefanidis $\mathrm{K}$, Nõges T, Nõges $\mathrm{P}$, Attayde JL, Zohary T, Coppens J, Bucak T, Menezes RF, Freitas FRS, Kernan M, Søndergaard M, Beklioğlu M (2015) Ecological impacts of global warming and water abstraction on lakes and reservoirs due to changes in water level and related changes in salinity. Hydrobiologia 750:201-227

Kalwasińska A, Jankiewicz U, Felföldi T, Burkowska-But A, SwiontekBrzezinska M (2018) Alkaline and halophilic protease production by Bacillus luteus $\mathrm{H} 11$ and its potential industrial applications. Food Technol Biotechnol 56:553-561

Keresztes ZG, Somogyi B, Boros E, Székely G, Bartha C, Nagy E, Dragoş N, Vörös L (2010) Picoplankton in soda lakes of the Carpathian Basin. Contrib Bot XLV:41-46

Khan MI, Shin JH, Kim JD (2018) The promising future of microalgae: current status, challenges, and optimization of a sustainable and renewable industry for biofuels, feed, and other products. Microb Cell Fact 17:36

Kirschner AK, Eiler A, Zechmeister TC, Velimirov B, Herzig A, Mach R, Farnleitner AH (2002) Extremely productive microbial communities in shallow saline pools respond immediately to changing meteorological conditions. Environ Microbiol 4:546-555

Kiss I (1971) A “meteorpapíros” és az alatta kialakuló Cyanophytatömegprodukciók vizsgálata a Szeged-környéki, a Dél-Alföldi és Duna-Tiszaközi szikes tavakban. A Szegedi Tanárképző Főiskola Tudományos Közleményei, pp 59-75. (in Hungarian with Russian and German abstract)

Kiss I (1976) Magyarország szikes tavaiban végzett hidrológiai és algológiai vizsgálataim áttekintése. A Szegedi Tanárképzô Főiskola Tudományos Közleményei, pp 51-69. (in Hungarian with Russian and German abstract)

Koblížek M (2015) Ecology of aerobic anoxygenic phototrophs in aquatic environments. FEMS Microbiol Rev 39:854-870

Korponai K, Szabó A, Somogyi B, Boros E, Borsodi AK, Jurecska L, Vörös L, Felföldi T (2019) Dual bloom of green algae and purple bacteria in an extremely shallow soda pan. Extremophiles 23:467-477

Krachler RF, Krachler R, Stojanovic A, Wielander B, Herzig A (2009) Effects of $\mathrm{pH}$ on aquatic biodegradation processes. Biogeosci Disc 6:491-514

Krammer M, Velimirov B, Fischer U, Farnleitner AH, Herzig A, Kirschner AK (2008) Growth response of soda lake bacterial communities to simulated rainfall. Microb Ecol 55:194-211

Langó Z, Borsodi AK, Micsinai A (2002) Comparative studies on Aeromonas strains isolated from Lakes Balaton (Hungary) and Fertő/Neusiedlersee (Hungary). Acta Microbiol Immunol Hung 49:37-45

Larsen JB, Larsen A, Bratbak G, Sandaa RA (2008) Phylogenetic analysis of members of the Phycodnaviridae virus family, using amplified fragments of the major capsid protein gene. Appl Environ Microbiol 74:3048-3057

Márton Zs, Csitári B, Szabó A, Székely AJ, Boros E, Felföldi T (2019) Mikroszkopikus eukarióták szezonális változása szikes tavakban. LXI. Hidrobiológus Napok, Tihany, 2-4 Oct 2019 [Conference presentation]

Newton RJ, Jones SE, Eiler A, McMahon KD, Bertilsson S (2011) A guide to the natural history of freshwater lake bacteria. Microbiol Mol Biol Rev 75:14-49

Padisák J (1992) Species composition, spatial distribution and the seasonal and interannual dynamics of phytoplankton in brown-water lakes enclosed with reed belts (Neusiedlersee/Fertő; Austria/Hungary). BFB-Bericht 79:13-29

Padisák J, Dokulil M (1994) Meroplankton dynamics in a saline, turbulent, turbid shallow lake (Neusiedlersee, Austria and Hungary). Hydrobiologia 289:23-42 
Pálffy K, Felföldi T, Mentes A, Horváth H, Márialigeti K, Boros E, Vörös L, Somogyi B (2014) Unique picoeukaryotic algal community under multiple environmental stress conditions in a shallow, alkaline pan. Extremophiles 18:111-119

Raven JA (1998) The twelfth transley lecture. small is beautiful: the picophytoplankton. Funct Ecol 12:503-513

Rothschild LJ, Mancinelli RL (2001) Life in extreme environments. Nature 409:1092-1101

Rusznyák A, Vladár P, Szabó G, Márialigeti K, Borsodi AK (2008) Phylogenetic and metabolic bacterial diversity of Phragmites australis periphyton communities in two Hungarian soda ponds. Extremophiles 12:763-773

Rusznyák A, Tóth EM, Schumann P, Spröer C, Makk J, Szabó G, Vladár P, Márialigeti K, Borsodi AK (2011) Cellulomonas phragmiteti sp. nov., a cellulolytic bacterium isolated from reed (Phragmites australis) periphyton in a shallow soda pond. Int J Syst Evol Microbiol 61:1662-1666

Schagerl M (ed) (2016) Soda lakes of East Africa. Springer, Cham

Selvarajan R, Felföldi T, Tauber T, Sanniyasi E, Sibanda T, Tekere M (2015) Screening and evaluation of some green algal strains (Chlorophyceae) isolated from freshwater and soda lakes for biofuel production. Energies 8:7502-7521

Somogyi B, Felföldi T, Vanyovszki J, Ágyi Á, Márialigeti K, Vörös L (2009) Winter bloom of picoeukaryotes in Hungarian shallow turbid soda pans and the role of light and temperature. Aquat Ecol 43:735-744

Somogyi B, Felföldi T, Dinka M, Vörös L (2010) Periodic picophytoplankton predominance in a large, shallow alkaline lake (Lake Fertő/Neusiedlersee). Ann Limnol Int J Limnol 46:9-19

Somogyi B, Felföldi T, Solymosi K, Makk J, Homonnay ZG, Horváth G, Turcsi E, Böddi B, Márialigeti K, Vörös L (2011) Chloroparva pannonica gen. et sp. nov. (Trebouxiophyceae, Chlorophyta)-a new picoplanktonic green alga from a turbid, shallow soda pan. Phycologia 50:1-10

Somogyi B, Felföldi T, Balogh KV, Boros E, Pálffy K, Vörös L (2016) The role and composition of winter picoeukaryotic assemblages in shallow Central European great lakes. J Great Lakes Res 42:1420-1431

Somogyi B, Pálffy K, Balogh KV, Botta-Dukát Z, Vörös L (2017) Unusual behaviour of phototrophic picoplankton in turbid waters. PLoS ONE 12:e174316

Sorokin DY, Berben T, Melton ED, Overmars L, Vavourakis CD, Muyzer G (2014) Microbial diversity and biogeochemical cycling in soda lakes. Extremophiles 18:791-809

Stenger-Kovács C, Lengyel E (2015) Taxonomical and distribution guide of diatoms in soda pans of Central Europe. Stud Bot Hung $46(S): 3-203$

Stiller J (1963) Zur Limnologie der Natrongewässer Ungarns I. Der Natronsee Nagyszék und seine Peritrichenfauna. Int Rev ges Hydrobiol 48:603-612

Stomp M, Huisman J, Stal LJ, Matthijs HCP (2007) Colorful niches of phototrophic microorganisms shaped by vibrations of the water molecule. ISME J 1:271-282

Szabó A (1999) Protozoológiai kutatások a HNP szikes biotópjaiban I. A vízi élőhelyek Ciliata faunája. Acta Biol Debr Oecol Hung 9:219-241 (in Hungarian)
Szabó A, Korponai K, Kerepesi C, Somogyi B, Vörös L, Bartha D, Márialigeti K, Felföldi T (2017) Soda pans of the Pannonian steppe harbor unique bacterial communities adapted to multiple extreme conditions. Extremophiles 21:639-649

Szabó A, Korponai K, Somogyi B, Vajna B, Vörös L, Horváth Z, Boros E, Szabó-Tugyi N, Márialigeti K, Felföldi T (2020) Grazing pressure-induced shift in planktonic bacterial communities with the dominance of acIII-A1 actinobacterial lineage in soda pans. bioRxiv. https://doi.org/10.1101/2020.06.04.133827

Szabó-Tugyi N, Vörös L, Balogh KV, Botta-Dukát Z, Bernát G, Schmera D, Somogyi B (2019) Aerobic anoxygenic phototrophs are highly abundant in hypertrophic and polyhumic waters. FEMS Microbiol Ecol 95:fiz104

Szuróczki S, Khayer B, Spröer C, Toumi M, Szabó A, Felföldi T, Schumann P, Tóth E (2019) Arundinibacter roseus gen. nov., sp. nov., a new member of the family Cytophagaceae. Int J Syst Evol Microbiol 69:2076-2081

Szuróczki S, Abbaszade G, Szabó A, Bóka K, Schumann P, Tóth E (2020) Phragmitibacter flavus gen. nov., sp. nov. a new member of the family Verrucomicrobiaceae. Int J Syst Evol Microbiol 70:2108-2114

Tóth A, Horváth Z, Vad CF, Zsuga K, Nagy SA, Boros E (2014) Zooplankton of the European soda pans: fauna and conservation of a unique habitat type. Int Rev Hydrobiol 99:255-276

Urbach E, Scanlan DJ, Distel L, Waterbury JB, Chisholm SW (1998) Rapid diversification of marine picophytoplankton with dissimilar light-harvesting structures inferred from sequences of Prochlorococcus and Synechococcus (Cyanobacteria). J Mol Evol 46:188-201

Vladár P, Rusznyák A, Márialigeti K, Borsodi AK (2008) Diversity of sulfate-reducing bacteria inhabiting the rhizosphere of Phragmites australis in Lake Velencei (Hungary) revealed by a combined cultivation-based and molecular approach. Microb Ecol 56:64-75

Vörös L, Boros E (2010) Nodularia willei Gardn. bloom: condition of planktonic and benthic primary production in a soda pond (Kelemen-szék). Acta Biol Debr Oecol Hung 22:139-152 (in Hungarian with English abstract)

Vörös L, Callieri C, Balogh KV, Bertoni R (1998) Freshwater picocyanobacteria along a trophic gradient and light quality range. Hydrobiologia 369(370):117-125

Vörös L, Somogyi B, Boros E (2008) Birds cause net heterotrophy in shallow lakes. Acta Zool Hung 54:23-34

Weisse T (1993) Dynamics of autotrophic picoplankton in marine and freshwater ecosystems. In: Jones JG (ed) Advances in microbial ecology, vol 13. Plenum Press, New York, pp 327-370

Wetzel RG (2001) Limnology-lake and river ecosystems. Academic Press, San Diego

Williams TJ, Wilkins D, Long E, Evans F, DeMaere MZ, Raftery MJ, Cavicchioli R (2013) The role of planktonic Flavobacteria in processing algal organic matter in coastal East Antarctica revealed using metagenomics and metaproteomics. Environ Microbiol 15:1302-1317 